\title{
Changes in Anatomic Structure of Burley Tobacco under the Influence of Irrigation and Fertilization*
}

\author{
by \\ V. Pelivanoska, K. Filiposki, and J. Trajkoski \\ Tobacco Institute Prilep, Kicevski pat bb, 7500 Prilep, Republic of Macedonia
}

\section{SUMMARY}

Investigations were made with the new burley variety B 2/93, bred in the Tobacco Institute Prilep, on alluvial soil type in the producing region of Ohrid and Struga. Four rates of nitrogen fertilizer $\left(55,100,150\right.$, and $\left.200 \mathrm{~kg} \mathrm{ha}^{-1}\right)$ and a constant rate of phosphorus and potassium were applied in the investigation.

Based on the results obtained, it can be stated that fertilization and irrigation have a significant influence on the anatomic structure of burley tobacco leaf. The best developed anatomic structure, with harmonically increased palisade and spongy parenchyma, was found in the variant fertilized with $150 \mathrm{~kg} \mathrm{ha}^{-1} \mathrm{~N}$. The cells of the parenchyma are not dense, and the spongy cells are few and irregularly distributed, forming large intercellular spaces between them. As a result of the interactive effect of irrigation and fertilization, this treatment is distinguished by a thick and soft leaf lamina with excellent adsorptive power, high filling capacity and, consequently, better quality. [Beitr. Tabakforsch. Int. 21 (2005) 345-349]

\section{ZUSAMMENFASSUNG}

Untersuchungen mit der neuen im Tabakinstitut Prilep gezüchteten Burley-Sorte B 2/93 wurden auf Alluvialböden der Region Ohrid und Struga durchgeführt. Vier verschiedene Stickstoffgaben (nur Unterhaltsdüngung, 100, 150 und $200 \mathrm{~kg} \mathrm{ha}^{-1}$ ) bei konstanter Menge Phosphor und Kalium wurden in den Untersuchungen angewandt.

Die dabei erhaltenen Ergebnisse zeigen einen bedeutenden Einfluss der Düngung und Bewässerung auf die anatomische Struktur des Burley-Tabakblattes. Die bestentwickelte anatomische Struktur mit harmonischer Zunahme des Palisaden- und Schwamm-Parenchyms wurde bei der Stickstoffdüngung mit $150 \mathrm{~kg} \mathrm{~N}^{-1}$ gefunden. Die Zellen des Parenchyms sind nicht dicht, und die Schwammparenchymzellen sind selten und ungleichmäßig verteilt, so dass zwischen ihnen große Interzellularräume entstehen. Als Ergebnis der Wechselwirkung von Bewässerung und Düngung zeichnet sich diese Variante durch ein dünnes und weiches Blatt mit ausgezeichneter Adsorptionskraft, hohe Füllkapazität und dadurch bedingte bessere Qualität aus. [Beitr. Tabakforsch. Int. 21 (2005) 345-349]

\section{RESUME}

Des essais ont été menés avec la nouvelle variété Burley B 2/93, sélectionnée à l'Institut de Tabac de Prilep sur un sol de type alluvial dans les régions tabacoles de Ohrid et Struga. Quatre niveaux de fertilisation azotée (55, 100, 150 et $200 \mathrm{~kg} \mathrm{ha}^{-1}$ ) avec un niveau constant de phosphore et potassium ont été appliqués dans cette étude.

Les résultats obtenus montrent que la fertilisation et l'irrigation ont un effet significatif sur la structure anatomique de la feuille du tabac Burley. La structure anatomique la mieux développée avec un accroissement harmonieux du tissu palissadique et des couches du parenchyme spongieux s'observe avec la variété fertilisée avec $150 \mathrm{~kg}$ $\mathrm{ha}^{-1} \mathrm{~d}$ 'azote. Les cellules du parenchyme ne sont pas denses et les cellules spongieuses sont rares et distribuées irrégulièrement, formant de grandes lacunes intercellulaires. Le résultat de l'interaction entre l'irrigation et la fertilisation, ce traitement mène à des parenchymes foliaires épais et tendres ayant une capacité d'adsorption excellente, un pouvoir de remplissage important et par conséquent une meilleure qualité. [Beitr. Tabakforsch. Int. 345-349] 
Table 1. Average thickness of the constituent parts of air-cured leaf tissue

\begin{tabular}{|c|c|c|c|c|c|c|c|c|}
\hline Treatments & $\begin{array}{c}\text { Upper } \\
\text { epidermis }(\mu \mathrm{m}) \\
\end{array}$ & $\%$ & $\begin{array}{c}\text { Palisade } \\
\text { parenchyma }(\mu \mathrm{m}) \\
\end{array}$ & $\%$ & $\begin{array}{c}\text { Spongy } \\
\text { parenchyma }(\mu \mathrm{m})\end{array}$ & $\%$ & $\begin{array}{c}\text { Lower } \\
\text { epidermis }(\mu \mathrm{m}) \\
\end{array}$ & $\%$ \\
\hline 1 & 26.64 & 100.00 & 57.53 & 100.00 & 98.09 & 100.00 & 15.90 & 100.00 \\
\hline 2 & 25.98 & 97.52 & 78.42 & 136.31 & 140.64 & 143.38 & 15.69 & 98.70 \\
\hline 3 & 24.42 & 91.66 & 83.80 & 145.66 & 160.13 & 163.24 & 14.28 & 89.81 \\
\hline 4 & 20.26 & 76.05 & 71.90 & 124.98 & 139.22 & 141.93 & 14.81 & 93.14 \\
\hline
\end{tabular}

\section{INTRODUCTION}

One of the basic characteristics of burley tobacco is its adsorptive power, i.e. the capacity to receive and keep sauces from $25 \%(7)$ to $50 \%(6,2)$ of its own weight. It is a result of the specific anatomic structure of leaves, i.e. well developed palisade and spongy parenchyma. Therefore, all necessary cultural practices should be applied to obtain a crop with thin and fine leaf tissue, well developed palisade and spongy structure, large intercellular spaces and higher filling capacity, which will improve tobacco usability.

Irrigation and fertilization, mainly by nitrogen, showed especially positive influence on anatomic structure of burley tobacco leaf, which was the subject of this investigation.

\section{MATERIALS AND METHODS}

Investigations were carried out with B 2/93, a new variety bred in the Tobacco Institute Prilep, on alluvial soil type, in the producing region of Ohrid and Struga. The trial was set up on an area of $2000 \mathrm{~m}^{2}$, and the following treatments were included:

- Treatment 1: fertilized during vegetation with $55 \mathrm{~kg}$ $\mathrm{ha}^{-1} \mathrm{~N}$

- Treatment 2: fertilized with $100 \mathrm{~kg} \mathrm{ha}^{-1} \mathrm{~N}$

- Treatment 3: fertilized with $150 \mathrm{~kg} \mathrm{ha}^{-1} \mathrm{~N}$

- Treatment 4: fertilized with $200 \mathrm{~kg} \mathrm{ha}^{-1} \mathrm{~N}$

The amounts of phosphorus $\left(\mathrm{P}_{2} \mathrm{O}_{5}\right)$ and potassium $\left(\mathrm{K}_{2} \mathrm{O}\right)$ were constant: $\mathrm{P}_{2} \mathrm{O} 5,150 \mathrm{~kg} \mathrm{ha}^{-1}$ and $\mathrm{K}_{2} \mathrm{O}, 120 \mathrm{~kg} \mathrm{ha}^{-1}$.

Traditional cultural practices were used in the trial.

During the growing period, dynamics of soil moisture was monitored at $50 \mathrm{~cm}$ depth. Moisture estimation was made by drying the soil at $105^{\circ} \mathrm{C}$ until constant weight. There was no difference in number of irrigations among treatments.

Time for irrigation was estimated on the basis of current soil moisture, field water capacity, depth of soil layer moistening and fertilizer treatment. Irrigation was carried out in furrows, using the water of the local river.

Tobacco was harvested in 6 primings, according to leaf ripeness, and air-curing was done under shade, with sufficient airflow. Leaves from the third priming were used during investigation to determine the effect of irrigation and mineral nutrition on their anatomic structure.

Photographs were taken through a light microscope, with special software connecting the microscope with the computer used for measuring the length of the cells in the leaf tissue.

\section{LITERATURE SURVEY}

DONEV (3) stated that leaves from the third priming show harmonic increase of the palisade and spongy tissue, which is an indication of a good saucing. Larger intercellular spaces in leaves allow greater amounts of sauces to be received through the stomata and stored in the palisade and the spongy parenchyma. It was determined, however, that sauces are not kept in intercellular spaces, but, due to osmosis, they penetrate into the cells of both parenchyma layers. NAUMOSKI et al. (4) stated that the main indicator of quality of burley tobacco is development of spongy structure of the leaf, which can be attained by constantly high soil and air humidity. Drying which takes place during certain stages of development results in a xerophytic structure of leaves, which largely diminishes the power of absorption. ARSOV (1) reported that fertilization with increased amounts of nitrogen, phosphorus and potassium does not impair the internal structure of leaf, but on the contrary, it contributes to harmonical increase of the palisade and spongy tissue. By fertilization with higher rates of NPK, intercellular spaces in spongy tissue become larger and, consequently, they can receive higher amount of sauces in the cells of both layers.

UZUNOSKI (6) reported that anatomic structure of the leaf is a variety characteristic which is expressed in various ways, depending on ecological conditions, primings and cultural practices applied. Of the latter, particularly important for leaf structure are: irrigation regime, topping and nitrogen fertilization. Reduced amount of water results in formation of thicker leaf tissue, with smaller cells and increased number of stomas in leaf epidermis. Similar effects are noticed in the case of insufficient amount of nitrogen in soil.

PELIVANOSKA (5), in her investigations with various rates of nitrogen fertilizer $\left(0,90,150\right.$ and $\left.240 \mathrm{~kg} \mathrm{ha}^{-1}\right)$ and soil moisture levels (50\% and $70 \%$ of field capacity), reported that increased nitrogen and water supply favour the development of palisade and spongy tissues and their intercellular spaces. The power of absorption and the capacity for retention of sauces are also increased, which is good for improving tobacco smoking quality.

\section{RESULTS AND DISCUSSION}

Thickness of different leaf tissues (upper and lower epidermis) and palisade and spongy parenchyma from X-section measurements are presented in Table 1 and Figures 1-4. 


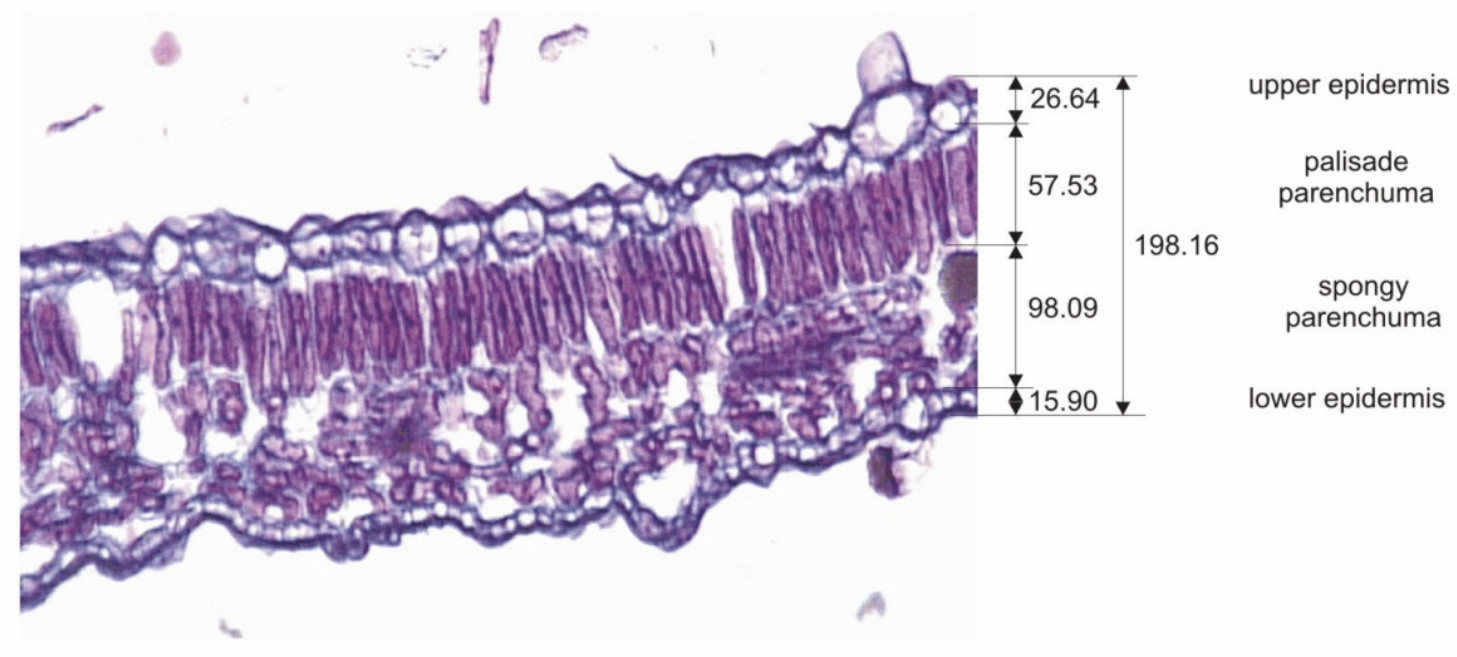

Figure 1. Changes in anatomic structure of tobacco type burley under the influence of irrigation and fertilisation (measured in $\mu \mathrm{m})$; Treatment 1



Figure 2. Changes in anatomic structure of tobacco type burley under the influence of irrigation and fertilisation (measured in $\mu \mathrm{m})$; Treatment 2

Treatment 1 is set as the base and the other treatments are compared as response relative to this treatment. The best results, with harmonic increase of palisade and spongy parenchyma, were obtained in Treatment 3 , fertilized with $150 \mathrm{~kg} \mathrm{ha}^{-1} \mathrm{~N}$. Palisade parenchymal cells are not as dense as the other trearments, and spongy cells are fewer and irregularly distributed, forming large intercellular spaces (Figure 3). All these data confirm that suitable irrigation and fertilization applied in this treatment resulted in production of tobacco with a thicker and open leaf structure.
As a result of irrigation and fertilization, this treatment is distinguished by well developed basic tissue and large intercellular spaces, which give it high adsorptive power, filling capacity and, consequently, better quality.

In Treatment 2, fertilized with $100 \mathrm{~kg} \mathrm{ha}^{-1} \mathrm{~N}$, no major differences were observed regarding the development of leaf parenchyma compared to Treatment 3 . In Treatment 4, however, regardless of the great amount of nitrogen fertilizer $\left(200 \mathrm{~kg} \mathrm{ha}^{-1}\right)$, there was no noticeable increase of the palisade and spongy parenchyma. This indicates that nitro- 


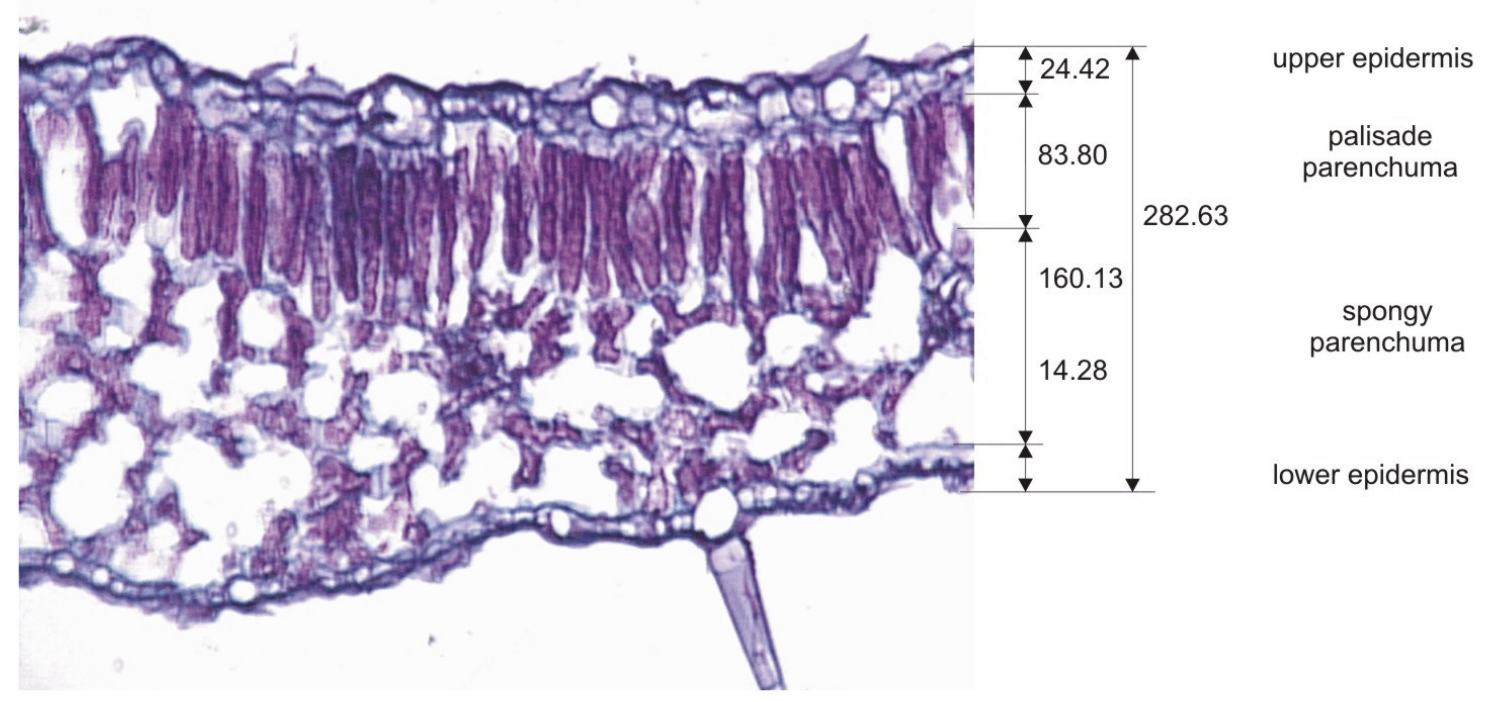

Figure 3. Changes in anatomic structure of tobacco type burley under the influence of irrigation and fertilisation (measured in $\mu \mathrm{m})$; Treatment 3

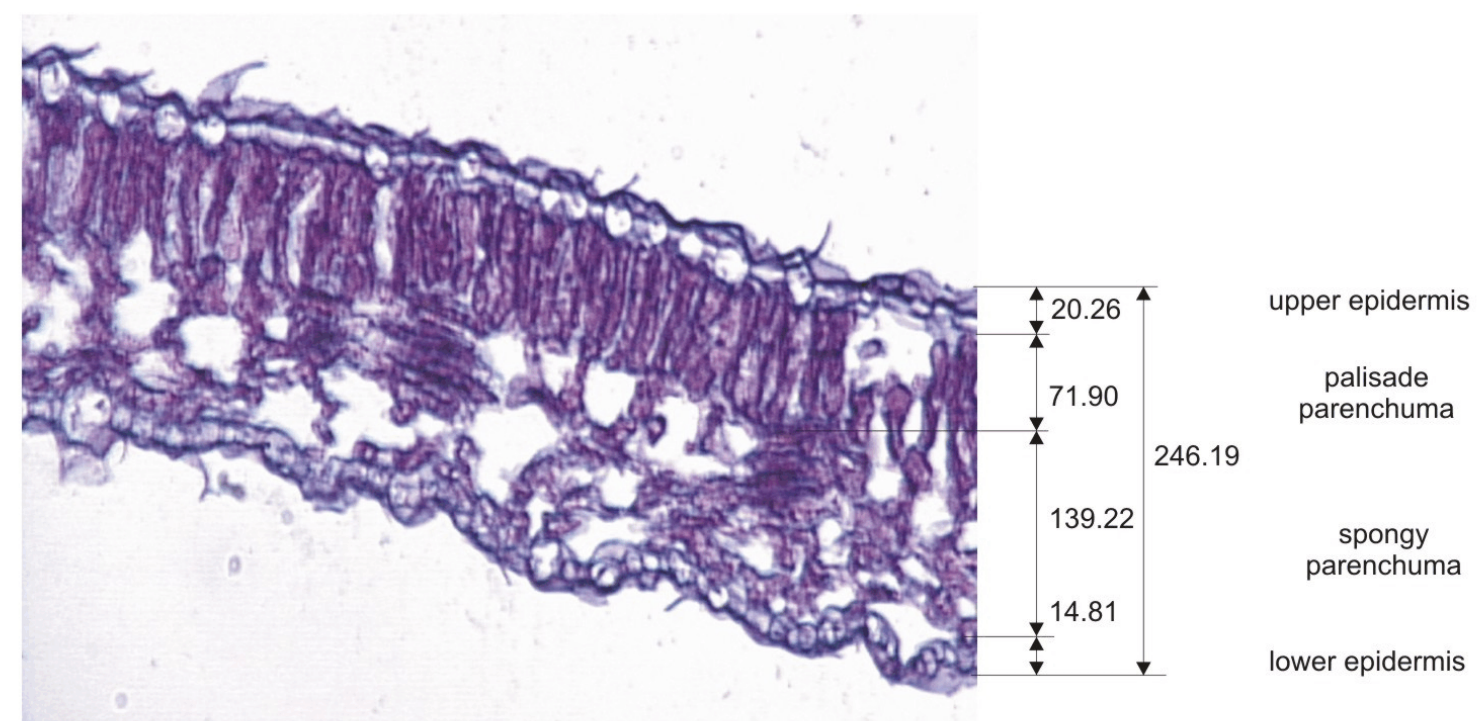

Figure 4. Changes in anatomic structure of tobacco type burley under the influence of irrigation and fertilisation (measured in $\mu \mathrm{m})$; Treatment 4

gen fertilizers can increase lamina cells up to a certain limit, but above that limit there is no further increased response.

Increased rate of nitrogen fertilizer reduced both the upper and lower epidermis in Treatments 1 to 4 (Table 1).

The effect of fertilization and irrigation on anatomic structure of leaf can be clearly identified on the photomicrograph of all four treatments (Figures 1-4).

\section{CONCLUSIONS}

Microscopic investigations were made on the effect of mineral fertilization and irrigation on anatomic structure of leaves in a trial with four treatments. They reveal that the treatment fertilized with $150 \mathrm{~kg} \mathrm{ha}^{-1} \mathrm{~N}$, in interaction with irrigation, gives plant material with the most useful parenchyma development. This is considered as high quality 
material, due to its high absorptive power for receiving and keeping great amounts of sauces in the process of saucing. Moreover, it also has a higher filling capacity which allows greater number of cigarettes to be produced from tobacco mass unit.

\section{REFERENCES}

1. Arsov, K: Mineral fertilizing and quality of Burley tobacco; Bulgarian Toutoun (Tobacco) No. 30-2, 27-31, ITTP - Plovdiv, 1985.

2. Devcic, K.: Burley tobacco response to the rate and time of application of calcium-ammonium nitrate (KAN) and urea; Doctoral dissertation, Tobacco Institut-Zagreb, 1-152, 1975.

3. Donev, N: A trial in technology of growing large-leaf tobaccos in Bulgaria. Achievements in tobacco production of the Peoples Republic of Bulgaria and Moldavian USSR; "Hristo G. Danow", Plovdiv, 1976.

4. Naumoski, K., D. Boceski, M. Grdanoski, S. Karajankov, and B. Ackoski: Contemporary tobacco production; "Nasa kniga", Skopje, 1977.
5. Pelivanoska, V. and J. Trajkoski: The irrigation and nutrition effect on the anatomic structure and some physical characteristics of tobacco type burley; Tutun/Tobacco, Vol. 49, No. 7-12, 101-110, Tobacco Institute-Prilep, 1999.

6. Uzunoski, M.: Initial results from the investigation of Burley tobacco in the region of Skopje; Tutun/Tobacco No. 7-8, 182-195, Tobacco Institute-Prilep, 1964.

7. Alic-Dzemidzic, N., J. Beljo, and M. Dzemidzic: Technology of manipulation and processing of tobacco; Tobacco Factory, Saraevo, 1999.

\section{Corresponding author:}

Valentina Pelivanoska Institut za tutun - Prilep Kicevski pat bb, 7500 Prilep Republic of Macedonia E-mail:vpelivanoska@yahoo.com 